\title{
IN SITU NITROGEN MANAGEMENT IN LANDFILL BIOREACTORS USING COMBINED SHARON AND ANAMMOX PROCESSES
}

\author{
S. Sri Shalini ${ }^{a, *}$ \\ Kurian Joseph \\ ${ }^{a}$ Research Scholar and ${ }^{b}$ Professor, Centre for Environmental Studies, \\ Anna University, Chennai, Tamil Nadu, India, Tel: 91-44-22301283
}

\begin{abstract}
Landfill bioreactors (LFBR) are gaining significant attention as sustainable alternative for conventional landfilling. Nitrogen management is an important issue in landfill bioreactors. The present study is to establish the combined SHARON (single reactor system for high activity ammonia removal over nitrite) and ANAMMOX (anaerobic ammonium oxidation) processes in landfill bioreactors for in situ nitrogen management. Laboratory scale landfill bioreactors (43 L volume capacity) as SHARON-ANAMMOX LFBR were loaded with mined municipal solid waste operated for 147 days at a nitrogen loading rate of $1.2 \mathrm{~kg}$ $\mathrm{N} / \mathrm{m}^{3} / \mathrm{d}$. The results showed a nitrogen removal efficiency of $84 \%$ with maximum partial nitritation efficiency of $56 \%$ and specific ANAMMOX activity of $0.7 \mathrm{mg} \mathrm{Amm-N/mg}$ MLVSS/d was achieved in the LFBR. Nitrogen transformations, biomass development and, hydrazine and hydroxylamine formation authenticated the aerobic ammonium oxidising bacteria (AOB) and anaerobic ammonium oxidising bacteria (AnAOB/ANAMMOX) activities responsible for combined SHARON-ANAMMOX processes in LFBR. 99\% of the biogas in LFBR as $\mathrm{N}_{2}$ the end product confirmed the combined SHARON-ANAMMOX processes. The study successfully demonstrated the combined SHARON-ANAMMOX processes for in situ nitrogen management in landfill bioreactors with shorter start-up time and stable operation.
\end{abstract}

\section{KEYWORDS}

Municipal solid waste; Landfill bioreactors; In situ nitrogen management; Combined SHARON and ANAMMOX processes; aerobic and anaerobic ammonium oxidising bacteria.

\section{INTRODUCTION}

Landfill bioreactors (LFBRs) are modified landfills with addition of moisture often leachate recirculation to accelerate the decomposition of waste and landfill gas generation [1]. The benefits of LFBRs are faster waste stabilisation rate, increased gas generation for energy recovery, in situ leachate treatment, increased landfill space capacity reuse, reduction in landfilling cost and environmental impacts. Even though LFBRs have many advantages the major constraint is persistence of ammonia nitrogen in the leachate in the range of 500 to over $5000 \mathrm{mg} / \mathrm{L}$ [1]. It tends to accumulate because there is no degradation pathway for ammonia

https://doi.org/10.15626/Eco-Tech.2014.032 
nitrogen in anaerobic systems. Ammonia nitrogen removal is important due to major environmental effects like aquatic toxicity, high oxygen demand in receiving waters and extended post closure care period of landfills. Novel processes such as combined SHARON (single reactor system for high activity ammonia removal over nitrite) and ANAMMOX (anaerobic ammonium oxidation) processes are gaining significant importance for removal of ammonia nitrogen from leachate. $50 \%$ ammonium is oxidised in the SHARON process to nitrite and then, the mixture of ammonium and nitrite in the ratio of 1:1.32 suited for the ANAMMOX process is anaerobically converted to nitrogen gas [2] (see Equation 1).

$$
2.3 \mathrm{NH}_{4}^{+}+2.95 \mathrm{O}_{2}+1.2 \mathrm{CO}_{2} \rightarrow 1.2 \mathrm{CH}_{1.8} \mathrm{O}_{0.2}+\mathrm{N}_{2}+0.3 \mathrm{NO}_{3}^{-}
$$

This combined SHARON-ANAMMOX processes has advantages when compared to the conventional nitrification and denitrification processes such as oxygen requirement is reduced by $60 \%$, external carbon source usage is reduced by $100 \%$, sludge production and $\mathrm{N}_{2} \mathrm{O}$ emission is also reduced [2, 3]. Aerobic and anaerobic ammonium oxidising bacteria (AOB and AnAOB) are the key players for the conducting the combined SHARON and ANAMMOX processes. The present study focuses on the application of combined SHARON and ANAMMOX processes for in situ nitrogen removal in landfill bioreactors. The performance of the combined SHARON-ANAMMOX LFBR were assessed by nitrogen transformations, biomass development and, hydrazine and hydroxylamine formation.

\section{MATERIALS AND METHODS}

\subsection{Landfill bioreactor setup}

The pilot scale landfill bioreactor was constructed using PVC pipe (see Figure 1). Landfill bioreactor dimensions were $0.21 \mathrm{~m}$ diameter, $1.20 \mathrm{~m}$ height and $43 \mathrm{~L}$ volume. LFBR consists of cover layer with sand $(0.1 \mathrm{~m})$, bottom layer with coarse gravel $(0.1 \mathrm{~m})$ as drainage layer and in between them mined municipal solid waste from dumpsite was fed as feed. PVC pipe was placed in LFBRs for gas collection and gas sampling. This PVC pipe was connected to a water displacement jar for gas measurement. Leachate from the LFBR was collected and recirculated into the LFBR once in a week.

\subsection{Landfill bioreactor operation and Analytical techniques}

SHARON process was initiated in the SHARON LFBR using enriched AOB biomass as seed from a laboratory scale reactor containing $43 \mathrm{~g} / \mathrm{kg}$ of VSS with AOB bacterial population of $1.9 \times 10^{4} \mathrm{MPN} / \mathrm{mL}$ of ammonium oxidizers. ANAMMOX process was initiated in the ANAMMOX LFBR using enriched AnAOB biomass from a laboratory scale reactor containing $43 \mathrm{~g} / \mathrm{kg}$ of VSS with AnAOB population of Candidatus Brocadia anammoxidans (GenBank accession number - JQ972060). After the 188 days of operation, the partial nitrified leachate from the SHARON LFBR $\left(0.99 \mathrm{~kg} \mathrm{~N} / \mathrm{m}^{3} / \mathrm{d}\right)$ was fed into ANAMMOX LFBR $\left(0.20 \mathrm{~kg} \mathrm{~N} / \mathrm{m}^{3} / \mathrm{d}\right)$ for operating it as SHARON-ANAMMOX LFBR. Then, it is recirculated into SHARON-ANAMMOX LFBR and was operated for a period of 147 days at a nitrogen loading rate of $1.2 \mathrm{~kg} \mathrm{~N} / \mathrm{m}^{3} / \mathrm{d}$. The $\mathrm{pH}$ and average temperature during the operation period was in the range of 7.0 to 8.0 and $31^{\circ} \mathrm{C}$, respectively. 


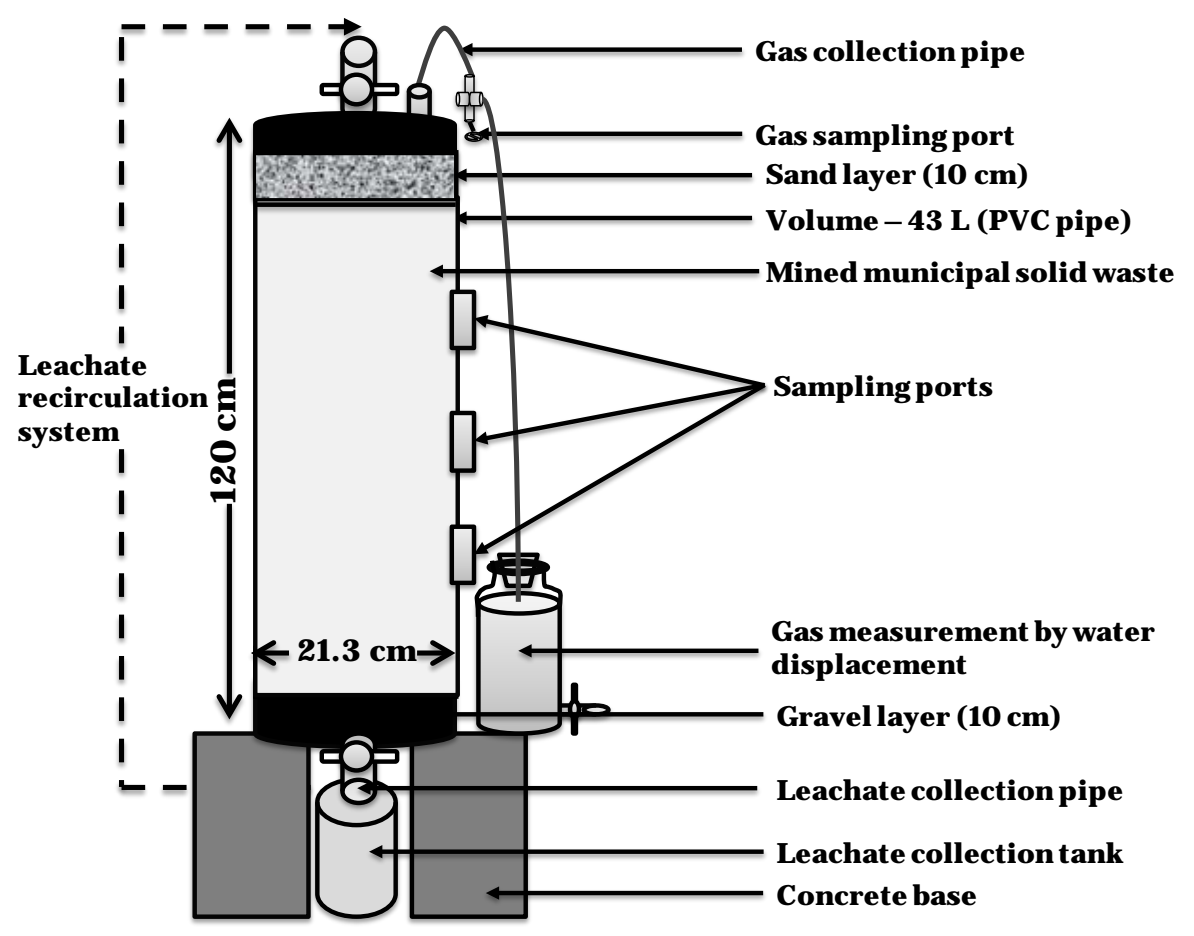

Figure 1. Schematic diagram of landfill bioreactor

Leachate was collected in air tight containers; weekly once for 147 days and analysis were carried out immediately on sample collection. The leachate collected $(100 \mathrm{~mL})$ for analysis was replaced by addition of water $(100 \mathrm{~mL})$ to the LFBRs. Leachate samples were analysed for ammonia nitrogen, nitrite and nitrate nitrogen according to standard methods [4]. The AOB and AnAOB biomass development was determined by trace appearance of intermediates such as hydrazine [5] and hydroxylamine [6] and bacterial biomass accumulation by MLVSS analysis. The nitrite accumulation rate in reactors was calculated by Partial Nitritation Efficiency (PNE) [7].

\section{RESULTS AND DISCUSSION}

\subsection{Nitrogen transformations in SHARON-ANAMMOX LFBR}

The variations in ammonia, nitrite and nitrate nitrogen in the SHARON-ANAMMOX LFBR are as seen in the Figure 2. The initial ammonia content in the reactor was $512 \mathrm{mg} / \mathrm{L}$ and reached maximum of $669 \mathrm{mg} / \mathrm{L}$ on $63^{\text {rd }}$ day. In situ ammonia nitrogen removal efficiency in SHARON-ANAMMOX LFBR reached $71 \%$ in the operational period. Nitrite utilisation was around $100 \%$ in the reactor. Kosari et al [8] reported SHARON process in SBR and ANAMMOX process in upflow fixed bed reactor. It gave ammonia and nitrite removal of $48 \%$ and $63 \%$, respectively. SHARON-ANAMMOX LFBR achieved higher removal rates than Kosari et al [8]. Low content of nitrite and nitrate around 0.0 to $24 \mathrm{mg} / \mathrm{L}$ in SHARONANAMMOX LFBR were due to immediate conversion of the compounds by the activity of AOB and AnAOB. The combined SHARON-ANAMMOX processes contributed to total nitrogen removal rate (NRR) of $0.998 \mathrm{~kg} \mathrm{~N} / \mathrm{m}^{3} / \mathrm{d}$ with nitrogen loading of $1.2 \mathrm{~kg} \mathrm{~N} / \mathrm{m}^{3} / \mathrm{d}$. The total nitrogen removal efficiency (NRE) achieved in the reactor was 84\% during the study period. NRE of SHARON-ANAMMOX LBFR was higher than that of the study by Li et al [9]. He reported partial nitritation-ANAMMOX processes in UASB at nitrogen loading of 1 to $2 \mathrm{~kg} \mathrm{~N} / \mathrm{m}^{3} / \mathrm{d}$ with NRE of $62 \pm 17 \%$. 


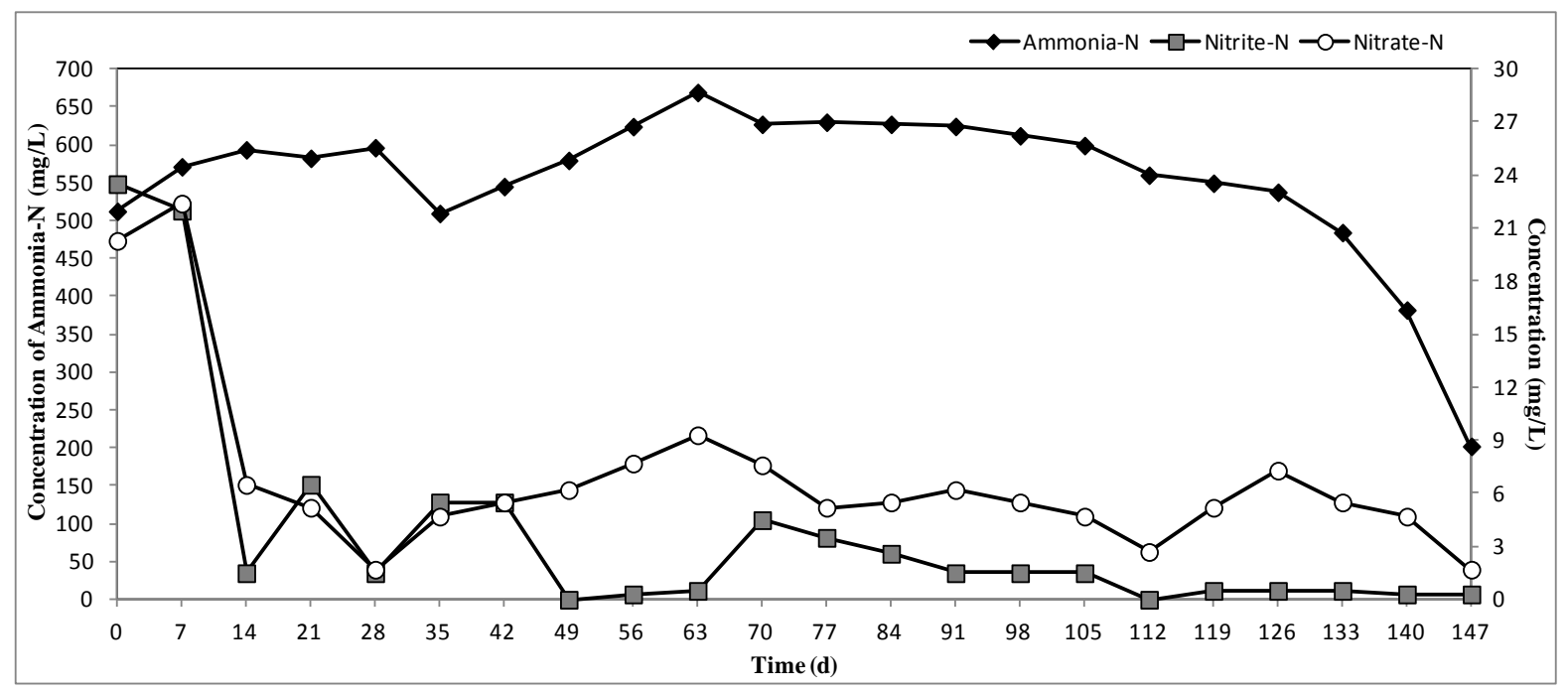

Figure 2. Nitrogen transformations in SHARON-ANAMMOX landfill bioreactor

The nitrogen removal performance of in situ combined SHARON-ANAMMOX LFBR is comparable with different ex situ combined SHARON-ANAMMOX reactors. Dongen et al [2] reported ex situ SHARON and ANAMMOX processes in a continuous stirred tank reactor (CSTR) and sequencing batch reactor (SBR) achieved a nitrogen removal of $80 \%$ with the nitrogen loading of $1.2 \mathrm{~kg} \mathrm{~N} / \mathrm{m}^{3} / \mathrm{d}$. Vazquez-Padin et al [10] achieved 69\% nitrogen removal in ex situ SBRs conducting SHARON and ANAMMOX processes at nitrogen loading of 0.28 $\mathrm{kg} \mathrm{N} / \mathrm{m}^{3} / \mathrm{d}$. The nitrogen removal was higher in the present study (84\%) with in situ combined SHARON-ANAMMOX processes in landfill bioreactor than other configurations.

\subsection{Biomass activity}

The AOB and AnAOB activity monitored during combined SHARON and ANAMMOX processes in the LFBR are as seen in the Figure 3.

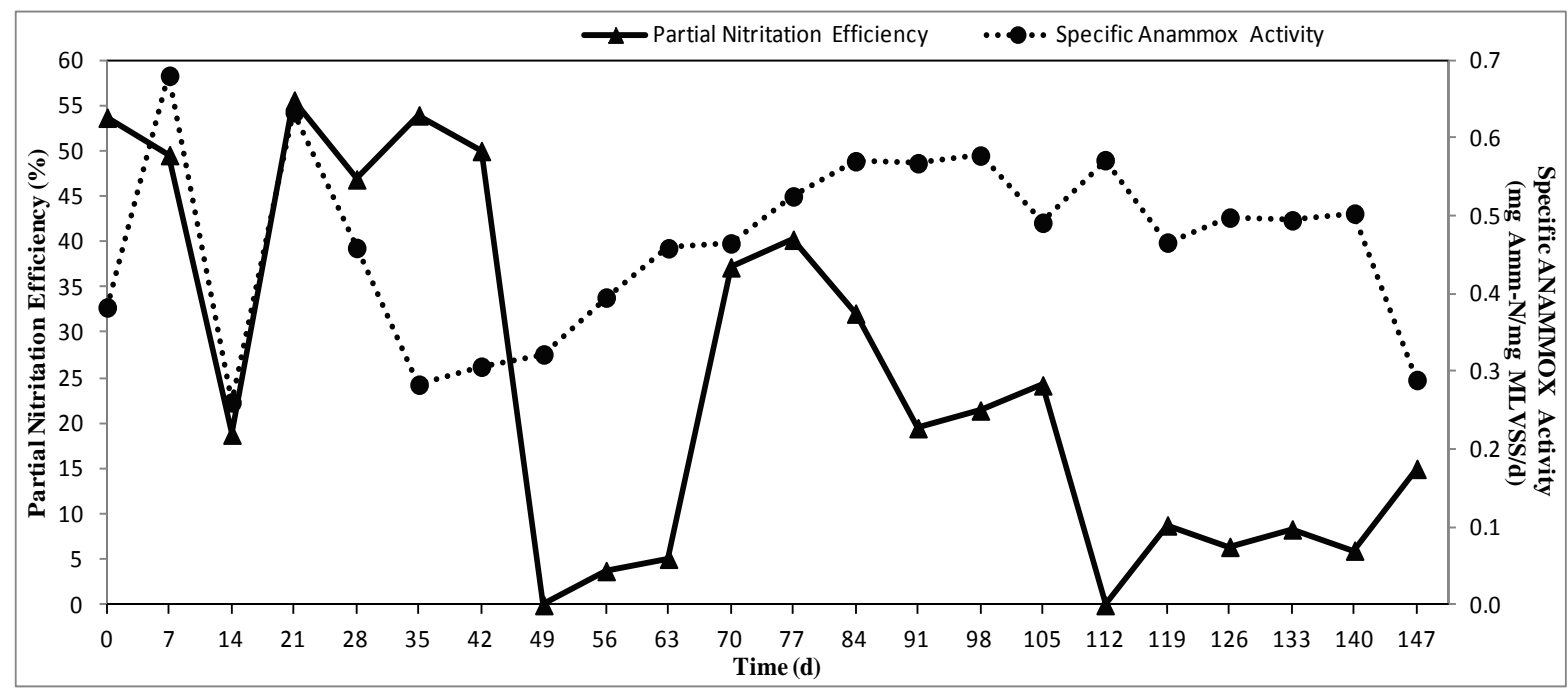

Figure 3. Partial Nitritation efficiency and specific ANAMMOX activity in SHARONANAMMOX landfill bioreactor 
For the first few weeks both SHARON and ANAMMOX processes were observed in the reactor by partial nitritation efficiency and specific ANAMMOX activity (SAA), respectively. The maximum PNE reached in the reactor was $56 \%$ on $21^{\text {st }}$ day. The SAA achieved in the reactor was around 0.3 to $0.7 \mathrm{mg}$ Amm-N/mg MLVSS/d. AOB existence was favourable to AnAOB population in the reactor. Since AOB consume if any oxygen prevail in the reactor thus protected the AnAOB population from exposure to oxygen. Partial nitritation efficiency decreased after day $21^{\text {st }}$ which consequently increased the specific ANAMMOX activity since favourable conditions for ANAMMOX process prevailed in the reactor. This was illustrated from the decreasing trend in PNE compliments with the increasing trend in SAA (see Figure 3).

The bacterial activity was also based on the free ammonia and free nitrous acid in the reactor as seen in the Figure 4. The free ammonia was in the range of 5.4 to $25.4 \mathrm{mg} / \mathrm{L}$ (except on day 266 with $61.3 \mathrm{mg} / \mathrm{L}$ ). The free ammonia was above inhibitory level of $0.1 \mathrm{mg} / \mathrm{L}$ for nitrite oxidising bacteria (NOB) which is the main competitor during the study period [11]. The free nitrous acid was in the range of 0.0 to $0.008 \mathrm{mg} / \mathrm{L}$. The free nitrous acid in the reactor was well below the inhibitory level $(0.2 \mathrm{mg} / \mathrm{L})$ for AOBs and AnAOBs [11]. Further, the bacterial activity was also demonstrated from the hydrazine and hydroxylamine in the reactor (see Figure 4). The hydrazine and hydroxylamine were in the range of 0.001 to $0.01 \mathrm{mg} / \mathrm{L}$ and 0.001 to $0.002 \mathrm{mg} / \mathrm{L}$, respectively. This authenticated the AOB and AnAOB activity [12].

The alkalinity in the range of 286 to $914 \mathrm{mg} / \mathrm{L}$ in the reactor maintained the $\mathrm{pH}$ during the study period. The alkalinity produced in ANAMMOX process neutralised acids from SHARON leachate. Thus, suitable $\mathrm{pH}$ was sustained during the combined process. The COD removal efficiency was low (45\%). Maximum biomass developed in the SHARONANAMMOX LFBR was $3280 \mathrm{mg} / \mathrm{L}$. The cumulative biogas generation in the reactor was 4.0 $\mathrm{L}$ in 147 days. Biogas composition in SHARON-ANAMMOX LFBR revealed the end product of the combined SHARON-ANAMMOX processes was $\mathrm{N}_{2}(99 \%)$ gas with the $\mathrm{N}_{2}$ concentration of $658 \mathrm{ppm}$.

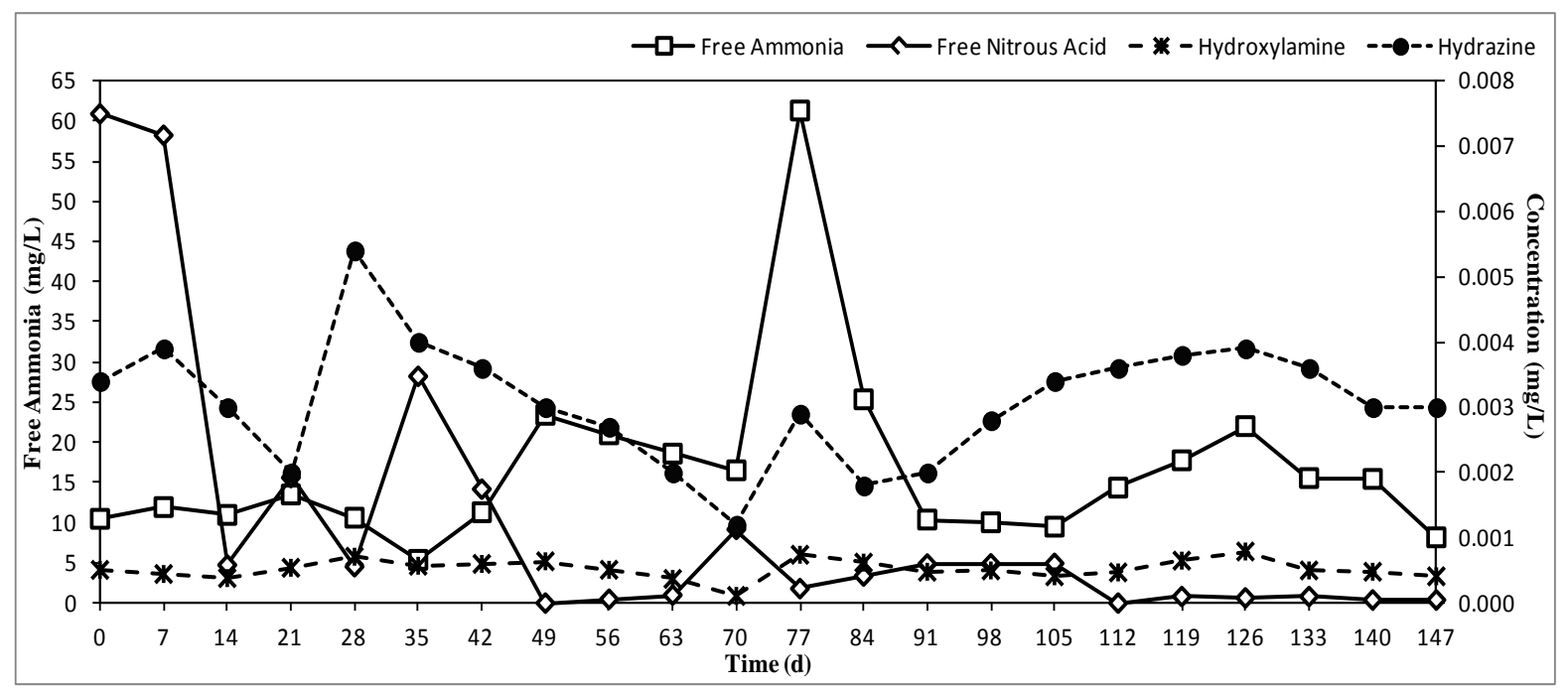

Figure 4. Free ammonia, Free nitrous acid, Hydrazine and Hydroxylamine in SHARONANAMMOX landfill bioreactor 


\section{CONCLUSIONS}

The study revealed the application of combined SHARON and ANAMMOX processes for in situ nitrogen removal in landfill bioreactors. The reactor performance of combined SHARONANAMMOX processes in landfill bioreactor demonstrated good performance in terms of higher nitrogen removal efficiency of $84 \%$ and ammonia nitrogen removal efficiency of $71 \%$ at nitrogen loading of $1.2 \mathrm{~kg} \mathrm{~N} / \mathrm{m}^{3} / \mathrm{d}$ in 147 days, biomass accumulation and easy operation. The end product of the combined SHARON-ANAMMOX processes was $\mathrm{N}_{2}$ (99\%) gas.

\section{ACKNOWLEDGEMENT}

The support of the All India Council for Technical Education to carry out this study in the form of National Doctoral Fellowship and fund from the Department of Science and Technology, Government of India to the corresponding author is gratefully acknowledged.

\section{REFERENCES}

1. Berge, N.D., Reinhart, D.R., Townsend, T.G., 2005. The fate of Nitrogen in Bioreactor landfills. Crit. Rev. Env. Sci. Technol. 35, 365-399.

2. Dongen, U., Jetten, M.S.M., van Loosdrecht, M.C.M., 2001. The SharonAnammox process for treatment of ammonium rich wastewater. Water Sci. Technol. 44, 153-60.

3. Kampschreur, M.J., van der Star, W.R.L., Wielders, H.A., Mulder, J.W., Jetten, M.S.M., van Loosdrecht, M.C.M., 2008. Dynamics of nitric oxide and nitrous oxide emission during full-scale reject water treatment. Water Res. 42, 812-826.

4. APHA, 1998. Standard Methods for the Examination of Water and Wastewater, $20^{\text {th }}$ edition, American Public Health Association/American Water Works Association/Water Environment Federation. Washington, DC, USA, ISBN 087553-235-7.

5. Watt, G.W., Chrisp, J.D., 1952. A spectrophotometric method for the determination of hydrazine. Anal. Chem. 24, 2006-2008.

6. Frear, D.S., Burrell, R.C., 1955. Spectrophotometric method for determining hydroxylamine reductase activity in higher plants. Anal. Chem. 27, 1664-1665.

7. Liang, Z., Liu, J.X., 2007. Control factors of partial nitritation for landfill leachate treatment. J. Environ. Sci.(China)19, 523-529.

8. Kosari, S.F., Rezania, B., Lo, K.V., Mavinic, D.S., 2014. Operational strategy for nitrogen removal from centrate in a two-stage partial nitrification-anammox process. Environ. Technol. 35 (9-12), 1110-1120.

9. Li, H., Zhou, S., Ma, W., Huang, P., Huang, G., Qin, Y., Xu, B., Ouyang, H., 2014. Long-term performance and microbial ecology of a two-stage PNANAMMOX process treating mature landfill leachate. Bioresour. Technol. 159, 404-411.

10. Vazquez-Padin, J., Fernadez, I., Figueroa, M., Mosquera-Corral, A., Campos, J., Mendez, R., 2009. Applications of Anammox based processes to treat anaerobic digester supernatant at room temperature. Bioresour. Technol. 100, 2988-2994. 
11. Anthonisen, A.C., Loehr, R.C., Prakasam, T.B.S., Srinath, E.G., 1976. Inhibition of nitrification by ammonia and nitrous acid. J. Water Pollut. Control Fed. 46, 835-852.

12. Shivaraman, N., Shivaraman, G., 2003. Anammox - A novel microbial process for ammonium removal. Curr. Sci. 84, 1507-1508. 